\title{
Students' Expectations Of A Career In Sales: A Comparison Of Finance And Marketing Majors
}

Ann T. Kuzma, Minnesota State University, Mankato, USA

John R. Kuzma, Minnesota State University, Mankato, USA

Harold F. Thiewes, Minnesota State University, Mankato, USA

\begin{abstract}
Many of the graduates majoring in Finance and Marketing will secure entry-level positions in sales, often beginning careers dedicated to the sale of financial products; yet, perceptions of this career vary significantly, dependent on a student's area of study. The purpose of this study is to compare and contrast the perceptions of Finance majors versus Marketing majors regarding entry-level career expectations. Students were surveyed in upper-level Finance and Marketing courses during the 2008 fall semester at a north-central state university concerning 1) their perceptions of the importance of various employment characteristics that they would consider in accepting their entry-level job and 2) the perceived importance of particular academic learning outcomes to the success of their career.
\end{abstract}

\section{INTRODUCTION}

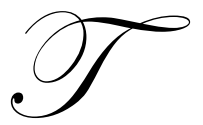

he recruitment of properly trained students for business careers in sales is a high priority for virtually all business organizations. The purpose of our study is to compare and contrast the perceptions of Finance majors versus Marketing majors regarding entry-level career expectations. We surveyed students in upper-level Finance and Marketing courses at a north central state university to examine the students' awareness of the importance of sales knowledge and communication skills in attaining their career expectations. Many of the Finance and Marketing majors will secure entry-level positions which will involve a high degree of selling; yet perception of future careers vary significantly, often dependent upon the majors selected in college.

The United States has experienced a long-term change from a goods-producing to a service-providing economy and this trend is expected to continue with service-providing industries expected to generate approximately 15.7 million new jobs over the 2008-16 period. Specifically over this period, employment in the education and health services is expected to grow by 18.8 percent, professional and business services by 23.3 percent, management, scientific and technical consulting by 78 percent, retail trade by 4.5 percent, and securities and financial investments by 46 percent. While services are expected to experience this growth, manufacturing employment is expected to decline by 10.6 percent ( 1.5 million jobs) over this same 2008-16 period (Tomorrow's Jobs, 2008).

However, necessary job skills can vary, depending on the specific company or industry. As an example, 2006 projections on employment in wholesaling and manufacturing forecast a nine percent growth rate over the 2006-16 period. There is often no formal educational requirement for sales representatives in the wholesale and manufacturing industry, although a bachelor's degree, specifically in employment involving technical and scientific products can be beneficial. Data from 2006 revealed that 27 percent of those employed in the wholesaling and manufacturing area held a high school degree or less, and only 38 percent held a bachelor's degree. For those working with technical products, a bachelor's degree is more valuable but courses in marketing, economics or a foreign language can be of value, even though many companies have formal training programs (Sales Representatives, Wholesale and Manufacturing, 2008). A study of desired job characteristics among four key 
consumer goods company recruiters in the United Kingdom found that teamwork, responsibility, extra-curricular interests and problem-solving abilities were highly desired characteristics among potential employees. Specific skills, such as IT, were felt to be less important since company training programs would provide the needed skills. Further, little research support was found that recruiters among these consumer goods companies would value a candidate more if they had even undertaken specific sales training (Murray and Robinson, 2001).

Previous projections have also forecast strong growth in sales-oriented careers, although the growth rates in the changing economy do adjust from previous forecasts. The current economic downturn has impacted employment growth in many areas, specifically the mortgage industry. As recently as 2004, Jobsinthemoney.com reported that, in 2003, financial advisors and mortgage sales were the largest areas for sales positions, and postings for all sales positions increased by five percent in the last six months of that year (February 2004). However, due to the recent economic downturn, a MortgageDaily.com study reported mortgage layoffs of approximately 50,000 jobs in the 2007 third quarter and more recently, further losses of 14,405 and 5,889 in the 2008 first and second quarters, respectively (US Mortgage Industry Employment Stabilizing, 2008).

Earlier projections for sales job growth are briefly presented to further emphasize the evolving demand for sales personnel. In 2002, projections for the decade forecasted growth in the hiring of retail salespersons to increase by $12 \%$, or 510,000 new jobs; sales supervisors by $8 \%$, or 193,000 new jobs; wholesale and manufacturing sales representatives by $6 \%$, or 111,000 new jobs, and financial services sales agents by $22 \%$ or 82,000 new jobs (Occupational Outlook Quarterly, 2002). The February 2004 article, “The Job Market Thaw", in the publication Sales \& Marketing Management, reported that companies were facing 2004 with increased revenue and one of the first areas of expansion for companies would be in sales, as many would be faced with too few salespeople. Further, the Association for Services Management International 2003 survey of 370 companies showed that the growth rate for service companies was double that of products, necessitating retraining for many sales reps who would change employment into the services industry, and also a re-examination of many of the sales training courses offered at universities (Cooley, 2004).

Although business demand for sales professionals has been and remains strong, studies have shown that students hold negative attitudes toward sales positions. Yet, virtually all career choices will involve a high degree of persuasion, selling and sales management. Accounting and finance professionals may have to persuade coemployees of the soundness of the budgetary plans; marketing professionals may have to convince accounting and finance of the soundness of the marketing venture and its economic feasibility; human resource professionals must persuade co-workers of the necessity of implementing new administrative guidelines. Thus, even though these occupations are not considered as being in the sales profession, they must often rely on persuasive and sales skills to accomplish their goals with customers, fellow employees and other stakeholders.

Despite the importance of professional selling skills, many college students maintain a negative perception of selling as a career. More than 20 years ago, Weeks and Muehling (1987) found that the traditional view of selling as a 'door-to-door' occupation remained strong among college students' perceptions of selling as a career. A previous study by Paul and Worthing (1970) found that students of all majors, in addition to business, held low images of selling careers. In contrast to the typical salesperson, college students believed a career in sales was less apt to provide certain positive aspects, such as status and security, but was more apt to provide the positive characteristics, such as rapid advancement and a considerable amount of leisure time (Dubinsky, 1981). Even though the majority of marketing programs at universities do not require students to take sales or sales management courses, Marketing majors who were surveyed eight years after graduation reported that sales courses were the third most important courses taken in their marketing curriculum (Kellerman and Hekmat, 1989). Later, Swensen, et al. (1993) found that personal selling careers continued to be unattractive to college students and that this negative view of a sales career increased as GPA increased among students. In contrast, they also found that college students highly rated certain attributes found in sales positions; specifically, salary, management responsibility and ability to make decisions. They concluded that recruiters could benefit by implementing strategies to promote sales careers among more students, not just those who seek interviews with their companies.

Del Vecchio and Honeycutt (2002) further examined the appeal of a sales career by contrasting black and white college students majoring in marketing. They found that race did not affect the perceived importance of 
salary, autonomy or education in evaluating a sales career, but neither black nor white students rated the appeal of either a consumer or industrial sales career very highly (both rating these careers at approximately 3 on a Likert scale of 1 to 5. Davis et al. (2002) found that while much attention in marketing courses was provided in the general marketing topics, these courses generally were deficient in providing the essential communication skills desired by practitioners. Marketing departments, as well as other business school departments, should strengthen connections with college and professional clubs and associations to provide an increased student focus on marketing careers and provide students with more realistic entry-level job expectations (McCorkle, et al, 2003).

\section{METHODOLOGY AND MEASURES}

Our sample consisted of 183 juniors and seniors who were taking marketing and finance classes at a north central state university. Our intent was to compare and contrast the entry level job expectations and desired job attributes of Finance and Marketing majors, as well as other business students. We also wanted to evaluate students' perceptions of the skills they felt were important to achieving success in their chosen careers

The students were asked to rank, on a scale of 1 (Very Unimportant) to 5 (Very Important) the importance that various job characteristics would have on their willingness to accept an entry-level position. Students were then asked to rate the importance of various academic outcomes in terms of the importance these outcomes would provide to their achieving success in their career.

\section{RESULTS}

The survey was completed by 183 students in upper division Finance and Marketing classes during the 2008 fall semester at a north central university. The listing in Table 1 provides a breakdown of the number of selfreported majors from the class surveys. Students were separated into two groups: 1) those majoring in Finance or double majoring in Finance and Accounting (Fin in tables), and 2) those majoring in Marketing, International Business or double majoring in Marketing and International business (Mkt in tables).

Table1

Respondents by Major

\begin{tabular}{|c|c|}
\hline 59 & Finance \\
\hline 25 & Finance/Accounting double majors \\
\hline 84 & Total: Sample 1 \\
\hline 78 & Marketing \\
\hline 8 & International Business \\
\hline 13 & Marketing/International Business double majors \\
\hline 99 & Total: Sample 2 \\
\hline
\end{tabular}

We first asked students to rate the importance of the following job characteristics on their importance in the students' acceptance of an entry-level position $(1=$ very unimportant and $5=$ very important, circle the appropriate number). Mean responses are provided in Table 2. In the far right column of the table, the t-statistic for the difference in the average response between the Accounting/Finance majors and the Marketing majors are presented. These t-statistics for the difference between majors are calculated as:

$\mathbf{t}=\left[\mathbf{X}_{\mathrm{Mkt}}-\mathbf{X}_{\mathrm{Fin}}\right] / \sigma_{\text {difference }}$

where $\mathrm{X}$ represents the means of the respective samples and $\sigma_{\text {difference }}$ is the standard deviation of the difference between the two samples and is calculated as:

$\sigma_{\text {difference }}=\left[\sigma_{\text {Mkt }}^{2} / N_{\text {Mkt }}+\sigma_{\text {Fin }}^{2} / N_{\text {Fin }}\right]^{1 / 2}$ 
where $\sigma$ is the standard deviation of the respective samples and $\mathrm{N}$ is the number of respondents in each sample.

While six of the 10 questions revealed no significant difference between the majors in job characteristics that would be important to them, the Marketing majors specifically rated three job characteristics, the ability to interact with others, the opportunity to travel, and the ability to use creativity much higher than the Finance majors. These differences were significant at the .01 . Another significant difference was found at the .05 level of significance regarding job security. Finance majors placed a higher level of importance on job security than did Marketing majors. Although there were significant differences between Finance majors and Marketing majors on the job characteristics identified above, it should be noted that both major groups rated these job characteristics very highly (over 3.6 on the $1-5$ scale).

Table 2

Importance of Job Characteristics for Entry-level Position

\begin{tabular}{|c|c|c|c|c|}
\hline Job Characteristic & $\underline{\text { Fin }}$ & $\underline{\text { Mkt }}$ & $\underline{\text { Diff }}$ & $\underline{t(\text { diff })}$ \\
\hline Ability to interact with others & $\overline{4.37}$ & $\overline{4.70}$ & $\overline{-0.33}$ & $-3.07 * * *$ \\
\hline Autonomy (be your own boss) & 3.17 & 3.14 & 0.03 & +0.18 \\
\hline Excellent fringe benefits & 3.81 & 3.65 & 0.16 & +1.43 \\
\hline High degree of Professionalism & 4.04 & 3.96 & 0.07 & +0.60 \\
\hline High potential income & 4.20 & 4.04 & 0.16 & +1.51 \\
\hline Job security & 4.54 & 4.33 & 0.20 & $+2.08 * *$ \\
\hline Opportunity to travel & 2.79 & 3.54 & -0.75 & $-4.76 * * *$ \\
\hline Provides challenges & 3.82 & 3.95 & -.012 & -1.10 \\
\hline Provides sense of accomplishment & 4.41 & 4.43 & -0.03 & -0.33 \\
\hline Use of creativity & 3.63 & 4.07 & -0.44 & $-3.04 * * *$ \\
\hline
\end{tabular}

**.05 significance, $* * * .01$ significance

Table 3

Outcome Importance to Developing a Successful Career

\begin{tabular}{|c|c|c|c|c|}
\hline Outcomes & $\underline{\text { Fin }}$ & $\underline{\text { Mkt }}$ & $\underline{\text { Diff }}$ & $\underline{t(\text { diff })}$ \\
\hline$\overline{\text { Ability to function as a team leader }}$ & $\overline{4.00}$ & $\overline{4.25}$ & $\overline{-0.25}$ & $-2.93 * *$ \\
\hline Ability to resolve conflicts & 4.20 & 4.35 & -0.15 & -1.54 \\
\hline Ability to simplify technical info to clients & 4.27 & 3.81 & 0.47 & $3.58 * * *$ \\
\hline Analyze market and competitive information & 4.13 & 4.08 & 0.05 & 0.39 \\
\hline Anticipate problems and provide solutions & 4.38 & 4.39 & -0.01 & -0.13 \\
\hline Comprehend quantitative job-related issues & 4.12 & 3.95 & 0.17 & 1.47 \\
\hline Effective listening capabilities & 4.44 & 4.56 & -0.12 & -1.20 \\
\hline Fluency in more than one language & 2.51 & 2.72 & -0.21 & -1.32 \\
\hline Identify relationships between varied problems & 3.86 & 3.90 & -0.04 & -0.39 \\
\hline Importance of contemporary technological skills & 4.12 & 3.94 & 0.18 & 1.63 \\
\hline Importance of appearance & 4.10 & 4.21 & 0.12 & -0.96 \\
\hline Persuasive oral communications skills & 4.23 & 4.47 & -025 & $-2.40 * *$ \\
\hline Strong negotiation techniques & 3.90 & 4.36 & -0.46 & $-3.72 * * *$ \\
\hline Relate to people with diverse backgrounds & 4.06 & 4.19 & -0.13 & -1.08 \\
\hline Written communications skills & 4.20 & 4.18 & 0.02 & 0.18 \\
\hline
\end{tabular}

**.05 significance, $* * * .01$ significance

The students next rated the outcomes listed below in terms of how they perceived whether these outcomes would provide value or be important to their career $(1=$ very unimportant and $5=$ very important. $)$ The average rating for each outcome is provided in Table 3. The data is presented in the same manner as that in Table 2. It is interesting to first note that four of the attributes exhibited significant differences at the .01 and .05 levels of significance when comparing the importance perceived between the two majors. Marketing majors perceived a higher level of importance in possessing strong negotiation techniques while Finance majors perceived the ability to simplify technical information to clients to be significantly more important than Marketing majors. Both differences were significant at the .01 level. Marketing majors indicated a higher level of importance to function as a team 
leader and possessing persuasive oral and communication skills (.05 level of significance) than the Finance majors. Again, although there were significant differences, both majors generally rated the outcomes highly. The only outcome to receive a rather neutral rating was the importance of being fluent in more than one language, even though such fluency was noted as of value to employers in the "Sales Representatives, Wholesale and Manufacturing" section of the 2008 Occupational Outlook Handbook.

Previous studies have found that students with higher levels of quantitative skills tended to major in Accounting or Finance, while those with weaker quantitative skills tended to major in Marketing and Management (Barnett, Dascher and Nicholson, 2004). One might expect that the communication outcomes would be more strongly emphasized in marketing curriculums relative to finance curriculums, resulting in the two groups rating these outcomes' importance differently. Barnett, et al. also reported that chairs of AACSB-accredited Marketing departments felt both written and oral communication ranked highest in importance for students majoring in Marketing (4.44 and 4.37 respectively on a 1-5 Likert scale). Results in Table 3 reveal similar findings among the Marketing majors in our study (4.20 and 4.23, respectively to these communication outcomes).

We had expected that most students would rank all outcomes rather highly and this was confirmed with no outcome receiving a ranking below 3.86 by finance majors and 3.81 by Marketing majors (Table 3). Accordingly, we asked all students to select and rank the five most important outcomes' important to developing a successful career. Students would simply place a 1 next to the outcome they felt was the most important, a 2 next to the $2^{\text {nd }}$ most important outcome, etc. and lastly, a 5 next to the $5^{\text {th }}$ most important. Table 4 indicates the number of students who selected a particular outcome as the $1^{\text {st }}, 2^{\text {nd }}, 3^{\text {rd }}, 4^{\text {th }}$ and $5^{\text {th }}$ most important outcome. To determine a composite score of outcome importance, if an outcome was selected as $1^{\text {st }}$ most important outcome, that number of students designating that outcome as $1^{\text {st }}$ was multiplied by 5; the number of students selecting the response as the $2^{\text {nd }}$ most important outcome was multiplied by 4 , etc., and lastly, the number of students selecting the outcome as the $5^{\text {th }}$ most important was multiplied by 1 . A total was then calculated for each outcome by adding the weightings. Table 4 lists the outcomes from highest to lowest ranking. As an example, the highest rated outcome was written communication skills, determined by $20 * 5+22 * 4+23 * 3+20 * 2+16 * 1=313$.

Table 4

Student Ranking of Top Five Outcomes on Importance to Career

\begin{tabular}{|c|c|c|c|c|c|c|}
\hline Outcomes & $\underline{1^{\text {st }}}$ & $2^{\text {nd }}$ & $\mathbf{3}^{\text {rd }}$ & $\underline{4}^{\text {th }}$ & $\underline{5}^{\text {th }}$ & $\underline{\text { Total }}$ \\
\hline 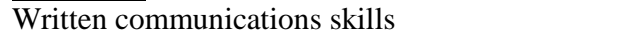 & $\overline{20}$ & $\overline{22}$ & $\overline{23}$ & $\overline{20}$ & $\overline{16}$ & 313 \\
\hline Effective listening capabilities & 37 & 11 & 14 & 11 & 13 & 306 \\
\hline Ability to resolve conflicts & 16 & 23 & 14 & 18 & 18 & 268 \\
\hline Ability to use varied communication styles & 16 & 20 & 16 & 14 & 14 & 250 \\
\hline Anticipate problems and provide solutions & 9 & 14 & 20 & 17 & 19 & 214 \\
\hline Persuasive oral communications skills & 16 & 12 & 10 & 16 & 18 & 208 \\
\hline $\begin{array}{l}\text { Importance of contemporary technological skills } \\
\text { (database and/or spread sheets management, etc.) }\end{array}$ & 15 & 12 & 14 & 15 & 8 & 203 \\
\hline Comprehension of quantitative job-related issues & 8 & 15 & 15 & 8 & 7 & 168 \\
\hline Strong negotiation techniques & 8 & 13 & 13 & 12 & 9 & 164 \\
\hline Importance of appearance & 6 & 8 & 6 & 20 & 11 & 131 \\
\hline Identify relationships between varied problems & 11 & 8 & 6 & 6 & 14 & 131 \\
\hline Ability to function as a team leader & 7 & 7 & 7 & 7 & 7 & 105 \\
\hline Analyze market and competitive information & 3 & 6 & 12 & 4 & 2 & 85 \\
\hline Ability to simplify technical info to clients & 2 & 3 & 4 & 7 & 16 & 64 \\
\hline Relate to people with diverse backgrounds & 2 & 1 & 1 & 0 & 3 & 20 \\
\hline
\end{tabular}

Table 4 presents the combined rankings for both the Finance and Marketing students. Although there were some ranking differences between the two samples, both samples ranked written communication skills, effective listening skills and the ability to resolve conflicts as the three more important outcomes. Further, both Finance and Marketing student samples rated the ability to relate to people with diverse backgrounds as the least most important outcome, which might also contribute to the students' overall perception of a weak need to be fluent in more than one language. The reader is advised to peruse Table 4 for specific total scores and the ranking of each outcome. 
Lastly, students were asked to view the following attributes as they applied to a career in selling (where 1 $=$ strongly agree $(\mathrm{SA}), 2=\operatorname{agree}(\mathrm{A}), 3=\operatorname{neutral}(\mathrm{N}), 4=\operatorname{disagree}(\mathrm{D})$, and $5=$ strongly disagree $(\mathrm{SD})$. Some of the questions were replicated from a study conducted by Amin, et al. (1995). Again, the average responses of the Finance and Marketing samples for each attribute are listed in Table 5. Overall, there was a high degree of agreement between the two majors. Only four of the 15 attributes exhibited significant differences between the two majors at the 10 percent significance level or higher. To elaborate, scores of 2 or higher were in agreement with the particular statement. Both majors felt sales careers attracted persistent, professional, friendly, exciting and responsible individuals. However, Marketing majors had a greater tendency to feel that salespeople were more professional and were more apt to be super achievers. Of further interest is that both groups did not differ on their recognition that sales jobs can require traveling and can lead to more stress than other occupations. Surprisingly, both groups were in agreement that a career in sales is not necessarily associated with high status, with both samples awarding the status question a relatively neutral rating of 3 .

Table 5

Importance of Attributes towards Career in Selling (5 point Likert scale: 1 = Strongly Agree; 5=Strongly Disagree)

\begin{tabular}{|c|c|c|c|c|}
\hline Attributes & $\underline{\text { Fin }}$ & $\underline{\text { Mkt }}$ & $\underline{\text { Diff }}$ & $\underline{t(\operatorname{diff})}$ \\
\hline$\overline{\text { Attracts people who are persistent }}$ & $\overline{1.67}$ & $\overline{1.735}$ & -0.07 & -0.58 \\
\hline Attracts people who are understandable & 1.98 & 2.04 & -0.06 & -0.52 \\
\hline Attracts people who are relaxed and secure & 2.44 & 2.37 & 0.07 & 0.45 \\
\hline Attracts people who are courteous and friendly & 1.99 & 2.02 & -0.03 & -0.24 \\
\hline Attracts people who are well educated & 2.37 & 2.12 & 0.16 & 1.07 \\
\hline Attracts people who are responsible & 2.35 & 2.11 & 0.24 & 1.39 \\
\hline Attracts people who are extroverted/persuasive & 1.58 & 1.61 & -0.03 & -0.26 \\
\hline Does not require weekend work all of the time & 2.96 & 3.02 & -0.57 & -0.35 \\
\hline High status & 2.96 & 2.88 & 0.09 & 0.68 \\
\hline Requires little traveling & 3.21 & 3.58 & -0.37 & $-2.41 * *$ \\
\hline Pays well & 2.38 & 2.37 & 0.01 & 0.07 \\
\hline Sales careers can be more stressful than most & 2.21 & 2.09 & 0.12 & 0.90 \\
\hline Salespeople tend to be boring & 3.49 & 3.78 & -0.29 & $-2.01 * *$ \\
\hline Salespeople are professional & 2.46 & 2.22 & 0.25 & $2.08 * *$ \\
\hline Salespeople are super achievers & 2.85 & 2.62 & 0.23 & $1.72 *$ \\
\hline
\end{tabular}

*.10 significance, $* * .05$ significance

\section{CONCLUSIONS}

Even though the majority of Marketing programs at universities do not require students to take sales or sales management courses, individuals employed in a marketing capacity rated sales courses taken in college as extremely valuable. We attempted to identify the different perceptions students hold towards a career in sales. We, also, tried to identify if there were differences between Finance majors and Marketing majors, not only in their attitudes towards sales but in their selection of entry-level careers that required sales as a primary function.

We found that, although some significant differences existed in perceptions of the importance of job characteristics, outcomes, and attributes of a career in sales, both Finance majors and Marketing majors had positive perceptions and attitudes towards sales attributes and careers. Marketing majors had slightly higher ratings than Finance majors, but both ratings were very positive. This seems to contradict previous studies.

It is important to note that all the job characteristic and outcomes were ranked highly by both the Finance majors and Marketing majors. The two majors were in agreement with chairs of AACSB-accredited Marketing departments that both oral and written communication skills were highly desirable outcomes necessary to develop a successful career. The only outcome that received a low ranking by both majors was the importance at having fluency in more than one language, which may run counter to what some organizations may desire when seeking potential sales representatives. This may identify a weakness in business education and guidance. 


\section{AUTHOR INFORMATION}

Dr. Ann Kuzma received her Ph.D. in Marketing from the Kent State University in 1989. She has taught at Minnesota State University from 1989 until the present and currently serves as chairperson of the Department.

Dr. John Kuzma received his Ph.D. in Marketing from the Kent State University in 1990. He has taught at Minnesota State University from 1989 until the present and is currently the Director of the Center for Sales Excellence at Minnesota State University, Mankato.

Dr. Harold Thiewes received his Ph.D. in Finance from the University of Iowa in 1990. He has taught at Minnesota State University and the University of Iowa from 1980 until the present and has previously served as Department Chairperson.

\section{REFERENCES}

1. Amin, Sammy G., Abdalla F. Hayajneh, and Hudson Nwakanma (1995). “College Students' Views of Sales Jobs as a Career: An Empirical Investigation.” American Business Review, (June), 54-60.

2. Barnett, Stephen T., Paul E. Dascher and Carolyn Y. Nicholson (2004), "Can School Oversight Adequately Assess Department Outcomes? A Study of Marketing Curriculum Content," Journal of Education for Business, (January/February), 157-164.

3. Cooley, Ryan, (2004), "Job Market Thaw," Sales \& Marketing Management, (February), 24-30.

4. Davis, Richard, Shekhar Misra, and Stuart Van Auken (2002), "A Gap Analysis Approach to Marketing Curriculum Assessment: A Study of Skills and Knowledge," Journal of Marketing Education, 24 (December), 218-24.

5. DelVecchio, Susan and Edar D. Honeycutt Jr (2002), "Explaining the Appeal of Sales Careers: A Comparison of Black and White College Students," Journal of Marketing Education, 24 (April), 56-63.

6, Dubinsky, Alan J. (1981), "Perceptions of Sales Job: How Students Compare with Industrial Salespeople," Journal of the Academy of Marketing Science, 9 (Fall), 352-67.

7. Kellerman, Bert J. and Firooz Hekmat (1989), "Personal Selling and Sales Management in the Marketing Curriculum: A Status Report," Journal of Personal Selling and Sales Management, 9 (Fall), pp. 35-45.

8. McCorkle, Denny E., Joe F. Alexander, James Reardon and Nathan D. Kling, (2003), "Developing SelfMarketing Skills: Are Marketing Students Prepared for the Job Search," Journal of Marketing Education, 25 (December), 196-207.

9. Murray, Sharon and Harry Robinson (2001), “Graduates into Sales - Employer, Student and University Perspectives, Education + Training, pp. 139-145.

10. Occupational Outlook Quarterly (2002), U.S. Department of Labor, Bureau of Labor Statistics (Spring), 28-29.

11. Paul, Gordon W. and Parker Worthing (1970), “A Student Assessment of Selling,” Southern Journal of Business, 5 (July), 57-65.

12. "Sales Representatives, Wholesale and Manufacturing" (2008), Occupational Outlook Handbook, 2008-09 Edition, U.S. Department of Labor, Bureau of Labor Statistics, www.bls.gov.

13. Swenson, Michael J., William R. Swinyard, Frederick W.Langrehr, and Scott M. Smith, (1993), "The Appeal of Personal Selling as a Career: A Decade Later," Journal of Personal Selling and Sales Management, Volume XIII, Number I (Winter), 51-64.

14. Tomorrow's Jobs (2008), Occupational Outlook Handbook, 2008-09 Edition, U.S. Department of Labor, Bureau of Labor Statistics, www.bls.gov. "US Mortgage Industry Employment 'Stabilizing”" (2008), Internet filing: Accounting/finance recruitment. North America (Posted July 07, 2008).

15. Weeks, William A. and Darrel D. Muehling (1987), "Students' Perceptions of Personal Selling," Industrial Marketing Management, 16 (May), 145-151. 
NOTES 